\title{
Living And Learning In Community: Blending Intentional And Learning Community On Campus
}

\author{
Patricia E. Calderwood \\ Fairfield University, pcalderwood@fairfield.edu
}

Follow this and additional works at: https://digitalcommons.fairfield.edu/education-facultypubs

The Journal of College and Character is sponsored by NASPA - Student Affairs Administrators in Higher Education, with support from the Hardee Center for Leadership and Ethics in Higher Education at Florida State University, and published by Berkeley Electronic Press.

http://journals.naspa.org/jcc/

PDF freely available at: http://journals.naspa.org/jcc/vol6/iss7/

\section{Peer Reviewed}

\section{Repository Citation}

Calderwood, Patricia E., "Living And Learning In Community: Blending Intentional And Learning Community On Campus" (2005). GSEAP Faculty Publications. 9.

https://digitalcommons.fairfield.edu/education-facultypubs/ 9

\section{Published Citation}

Calderwood, P. E. (2005). Living And Learning In Community: Blending Intentional And Learning Community On Campus. Journal of College and Character, 6 (7).

This item has been accepted for inclusion in DigitalCommons@Fairfield by an authorized administrator of DigitalCommons@Fairfield. It is brought to you by DigitalCommons@Fairfield with permission from the rightsholder(s) and is protected by copyright and/or related rights. You are free to use this item in any way that is permitted by the copyright and related rights legislation that applies to your use. For other uses, you need to obtain permission from the rights-holder(s) directly, unless additional rights are indicated by a Creative Commons license in the record and/or on the work itself. For more information, please contact digitalcommons@fairfield.edu. 


\title{
Journal of College and Character
}

Volume 6, Issue 7 2005

Article 9

\section{Living and Learning in Community: Blending Intentional and Learning Community on Campus}

\author{
Patricia Calderwood*
}

*Fairfield University

Copyright (c) 2005 by the authors. All rights reserved.

http://journals.naspa.org/jcc 


\title{
Living and Learning in Community: Blending Intentional and Learning Community on Campus
}

\author{
Patricia Calderwood
}

\begin{abstract}
This paper examines the social construction of community within a blended intentional and learning community, anchored in an exploration of three questions (who am I, whose am I, and who am I called to be).
\end{abstract}




\title{
Living and Learning in Community: Blending Intentional and Learning Community on Campus
}

\author{
Patricia E. Calderwood, Fairfield University
}

\begin{abstract}
This paper examines the social construction of community within a blended intentional and learning community, anchored in an exploration of three questions (who am I, whose am I, and who am I called to be).
\end{abstract}

\section{Introduction}

Who am I? Whose am I? Who am I called to be? Questions such as these occupy the minds of many young adults, but infrequently connect academic, social, and residential experiences on campus. For many college students, these fundamental questions of identity are experienced as lines of solitary inquiry disconnected from work, play, and rest (Armstrong, 1999; Astin, 1993; Baxter Magolda, 1993; Braxton \& McClendon, 2001; Calderwood, 2000a, b; Cohler \& Taber, 1993; Hartley \& Hollander, 2003; Jacoby, 1997; Pike, 1999; Schroeder \& Hurst, 1996; Rosenberg, 2002; Smith, 2003; Taub, 1998; White \& Porterfield, 1993).

In light of the research calling for innovative responses to the need to infuse such questions of identity into a comprehensive whole, and supported by a substantial grant sponsored by a private foundation, a mid-sized Jesuit university in the northeast USA has initiated the Ignatian Residential College (IRC). The fundamental orientation of the residential college, which houses and educates about $25 \%$ of the sophomore class at the university, is to examine vocation within a comprehensive residential and academic community. The students live together in one dorm, take two courses from a roster of approximately two dozen specially designed and designated core curriculum courses offered during the academic year, and meet regularly with mentors. Two co-directors manage the many routine and special activities, coordinate mentor groups, and coordinate sponsorship of University events with other campus organizations (Redmond, 2003). There are numerous special and daily events available for the students, staff, and faculty that blur academic and residential distinctions, such as group dinners, mentor groups, guest speakers, opportunities for community service, excursions, weekend retreats, parties, optional prayer groups, religious services, and so on. In addition, substantial faculty development opportunities are offered to all interested University faculty, both those who offer IRC courses and those who do not. This paper describes some indicators of student sense of community gleaned from a qualitative study of the first two years of the Ignatian Residential College.

Patricia Calderwood is an associate professor of Curriculum and Instruction at Fairfield University and the author of Learning Community: Finding Common Ground in Difference. Her current research focuses on building community for social justice. 


\section{Research Methodology}

Tn order to learn more about the construction of community within the Ignatian Residential College, I utilized ethnographic methodology and perspectives (Ellen, 1984; Strauss and Corbin, 1990). Interviews with participating faculty, staff, and students; surveys of students and faculty in each course; residence surveys of students and resident advisors; and ongoing analysis of varied media such as student essays, application and review forms, recruiting posters, the website, photographs, videos, news articles, and the papers, photos posters and artwork that adorn the corridors, bulletin boards, and doorways of Loyola Hall informed participant observation. Surveys were distributed to every student and faculty participating in an Ignatian Residential College course in the falls of 2002 and 2003, and the springs of 2003 and 2004. Residentially focused surveys were distributed to Loyola Hall residents and resident advisors in the spring and fall of 2003 and the spring of 2004. Co-directors shared with me approximately 4 dozen student reflective essays written during April 2003 and about 6 dozen written in April 2004. Confidential interviews focused on students' expected and actual academic, residential, social, and personal development experiences.

During my analysis of data, a colleague provided access to a database he had developed that allowed comparison of grades between the general student population and the first two cohorts of Ignatian Residential College students, represented in Figures 2 and 3 (Naser, 2004). Additionally, I used a previously developed framework (creating identity, accounting for difference and diversity, learning how to be in community, and celebrating community) to understand the construction of community (Calderwood, 2000a; 2003; see also Cohen, 1985, 1994; Frazer, 1999; Knight-Abowitz, 1997; Magolda, 2000).

\section{The Framework Of Community}

$\mathrm{T}$ he idea of community has been a thick thread woven through the words and activities of students in the IRC. As in other communities, important elements in the creation of group identity are the negotiation of inclusion and exclusion, and the related determination of internal distinctions that matter to the insiders. Students in the IRC needed to learn how to be in community, celebrated with periodic ceremonies, rites of passage, and other events. This led to a sense of community, of belonging and caring, among the group members.

At least two distinct types of community are evident, each a constituent of the other. The first, an intentional community, as one of the co-directors has labeled it (Lederer, personal communication, spring 2003), is brought together through spiritual and religious explorations of vocation. The second, a learning community, is animated by the possibility of the discovery of vocation through academic avenues. Three questions of identity (Who am I? Whose am I? Who am I called to be?) are asked and explored no matter which aspect of community, intentional or learning, is foregrounded. The pervasiveness of the questions continually brings elements of a learning community to the practices of the intentional community, and, to a lesser extent, brings the focal point of identity search, particularly the search for vocation, into the formal learning community. Vocation, as several social scientists have noted, is a feeling of being called toward the life to which one is destined. One common use of the term has vocation being, more specifically, a call to a religious life; a second captures the action and purposefulness of one's career or occupation (Haworth, Cooper, Sucher \& Sullivan, 2004; Palmer, 2000). 
Some see the intentional community of the IRC to be bounded by its immediate membership and physical setting, but for others it is seen as a subset of spiritual community and/or faith community. The co-existing viewpoints about the boundaries of intentional community create one of the fault lines of vulnerability for the community, as both attract and repel potential participants. The student newspaper captured the duality of the attraction and repulsion in reporting that some (non-member) students were sardonically referring to the IRC as a cult, and that others were resentful of the enhanced living quarters or special events offered to the members.

The term "learning community" is most often used as a label for a group of students and a teacher who are consciously using hallmarks of communal affiliation, such as interpersonal relationships, and approaches such as interdependence of work, to construct knowledge so that all (including the teacher) might become more expert in the subject studied (Rogoff, 1994). Barbara Leigh Smith (2003) notes elements of successful learning communities: "a culture that builds trust and encourages students to get to know one another, high expectations and challenging assignments, interdisciplinary themes, and collaborative activities (p. 17)." Classes constructed as learning communities are uncommon configurations in undergraduate education, although informal learning communities, such as study groups, are more common (Schroeder \& Hurst, 1996; Taub, 1998). In the IRC, student responses to course surveys each semester of the study consistently point to hallmarks of strong learning community, such as knowing each other, having a voice, deep engagement with the course content, and a feeling of closeness, when they write about how the Ignatian courses differ from others. See Figure 1 below.

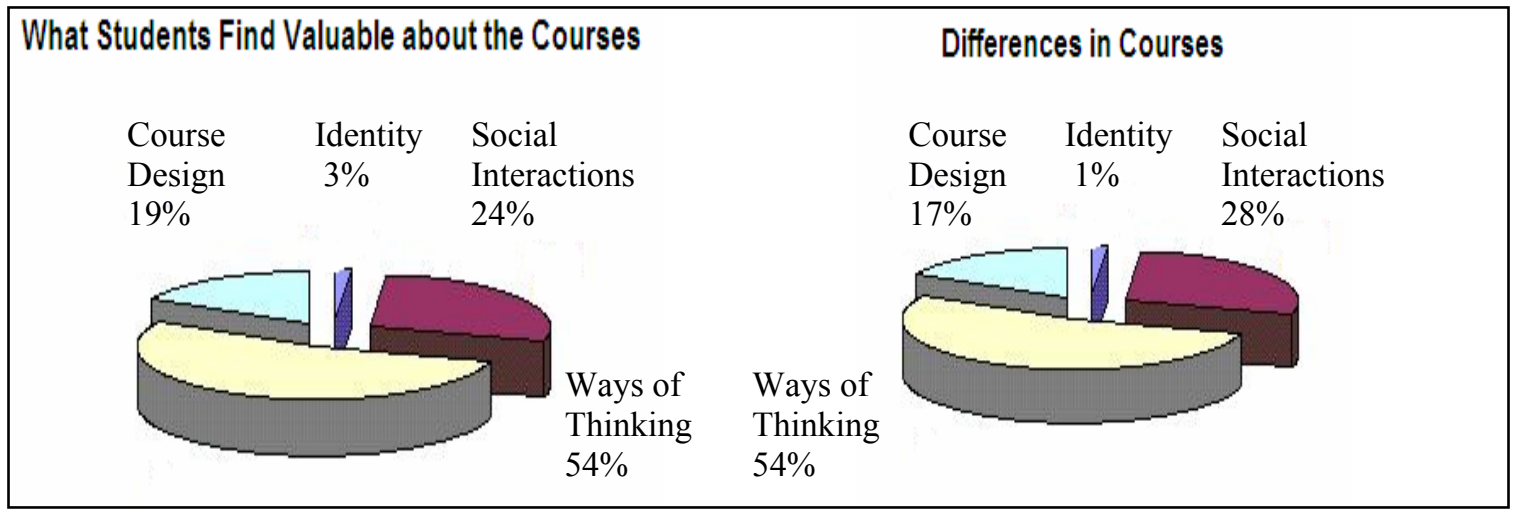

Figure 1: What Students Find Valuable and Meaningful in IRC Courses

The Ignatian Residential College community is particularly vibrant when the distinctions blur between intentional and learning community. Many of the classes are conducted in a makeshift classroom centered between the second floor dorm rooms. The classroom's location allows for a number of faculty to catch unexpectedly intimate glimpses of student life in the intentional community, prompting several of the more amusing and disconcerting anecdotes of border crossings on the campus.

\section{Identity Within Community}

$\mathrm{T}$

here is a frisson of tension surrounding the question of whether there is a particular kind of student who identifies as a member of the Ignatian Residential College. After hearing one of 
the faculty leaders unselfconsciously use the term "our kind of student" several times, I asked if "there is a particular kind of student desired. If so, who is that student? Who is the student who doesn't belong (Calderwood, notes 8/18/03)?"

In response, one of the co-directors responded thoughtfully:

As far as we are concerned we would take great pride if the Ignatian Residential College were one of the most diverse "student groups" on campus (as I believe we were last year). Granted it would make the job of the Ignatian Residential College a lot easier and simpler if we were preaching to the choir so to speak, but we are not necessarily looking for ease at the expense of a rich community experience one of the many places we believe learning outside of the classroom can take place here at Fairfield is through the experience of the "other" in the context of a community experience where difference and diversity are welcomed.

So we are not looking for a particular type of student in regard to ethnic, cultural, or faith backgrounds, but I would argue we are looking for students who are willing to be engaged in the program - participate with openness. With that said we will always have students with varying degrees of commitment and a wide variety of reasons for being here, whatever those reasons may be- even if it is for the Commons. I think they were "moved" to be here for a reason and will glean something of the year. Will we still have a screening process? yes. (T. Lederer, personal communication, $8 / 20 / 03$ ).

The first year profile of the 130+ IRC students was described to me by one of the resident Jesuits as more diverse than that of the university's undergraduate population in general. He noted that all the sophomores on the men's hockey team were residents, for example, and that the concentration of AHANA (African-American, Hispanic, Asian and Native American) students in the program was higher than the campus average, which he saw as belying a misconception that the program was only attracting religiously devout students. While acknowledging that the relatively posh dorms and comfortable common room were probably the biggest draw for the first year's students, he noted that the most common reason cited by the AHANA students was a desire for community and connection that they had not yet established on campus. The desirability of the living quarters continued to be a significant draw during the second year, along with the promise of numerous cultural/entertainment perquisites, such as trips to NYC theaters and free tickets to on-campus events. The second year, more students told me that their desire to room, or at least share a residence hall, with their existing friends was more likely attainable in the IRC than through the campus housing lottery. Again, the theme of desiring connection and community was strong. In both years, more women applied for residence than men, a trend that has continued in the third year applications.

Comparison of the general student population with the IRC students indicates that for the first two cohorts, sophomores entered the IRC with higher GPAs than their non-IRC peers, and maintained these differences over time. Their pattern of rising GPAs mirrored the larger population, and maintained the general grade differences between males and females (see Figure 2 ). This pattern generally holds for the third cohort, although the entering GPA of the male students in the third cohort was higher than for the general population of non-IRC women, most likely a result of the tighter entrance screening, described briefly in Figure 2. 
IRC vs. Class GPA Comparison by Semester: 200109F Cohort

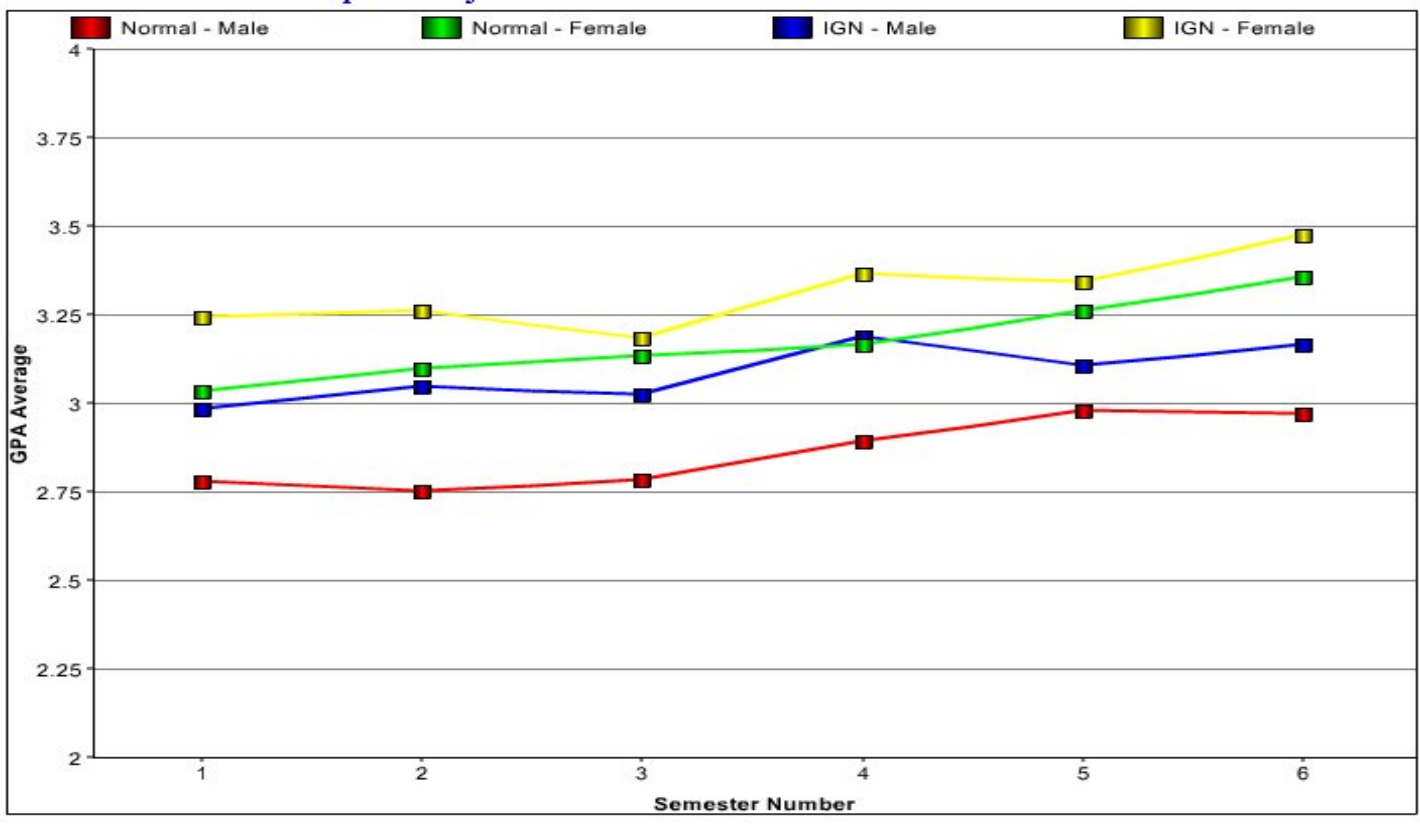

IRC vs. Class GPA Comparison by Semester: 200209F Cohort

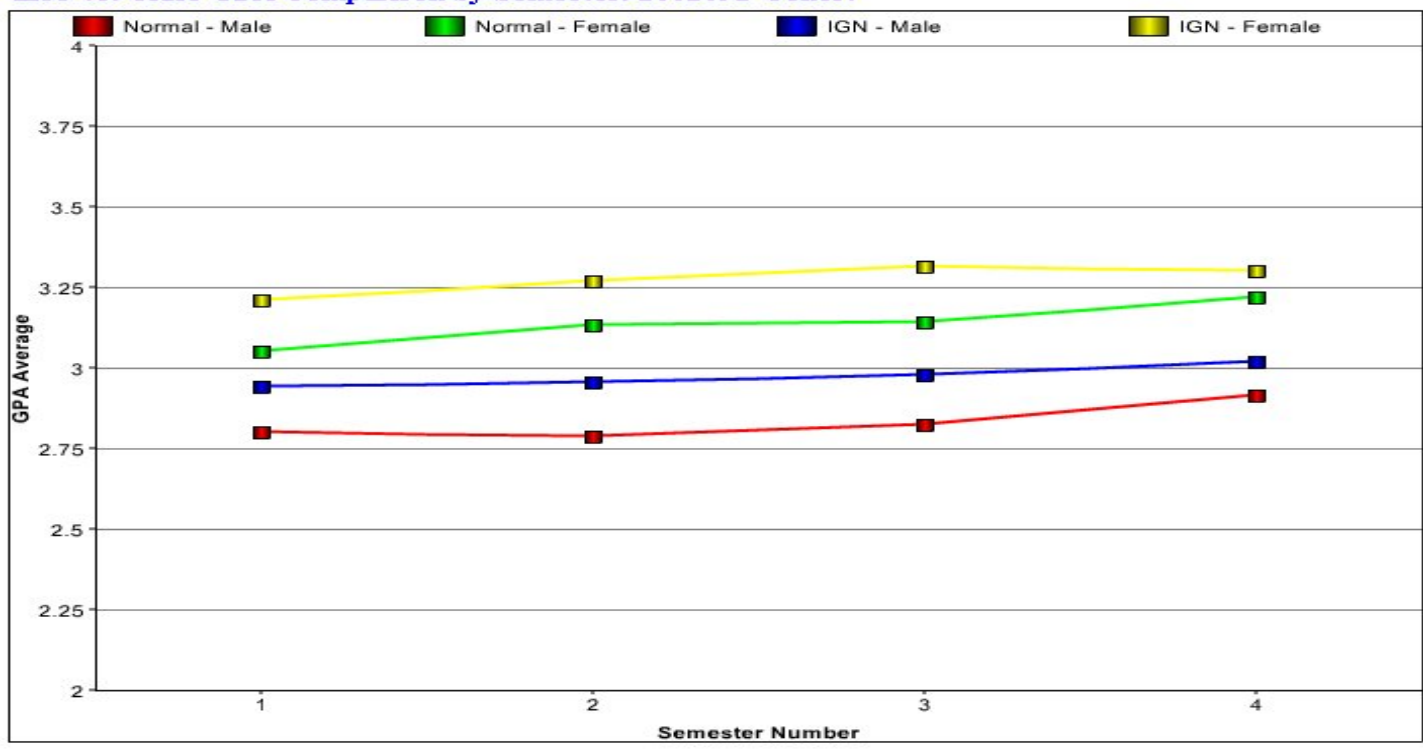

Figure 2: GPA Development by Cohort

The aggregated data for the 2001 cohort do not show large differences in the pattern of retention between the IRC and non-IRC students during their senior year (see Figure 3); however, although there was a moderate to large difference positive difference in the retention pattern for IRC compared to non-IRC students in the 2002 cohort during their junior year, there was a larger withdrawal rate among the female IRC students by their senior year $(27.4 \%)$ than in the general population (19.3\%) (Data courtesy of C. Naser, August 14, 2005). 


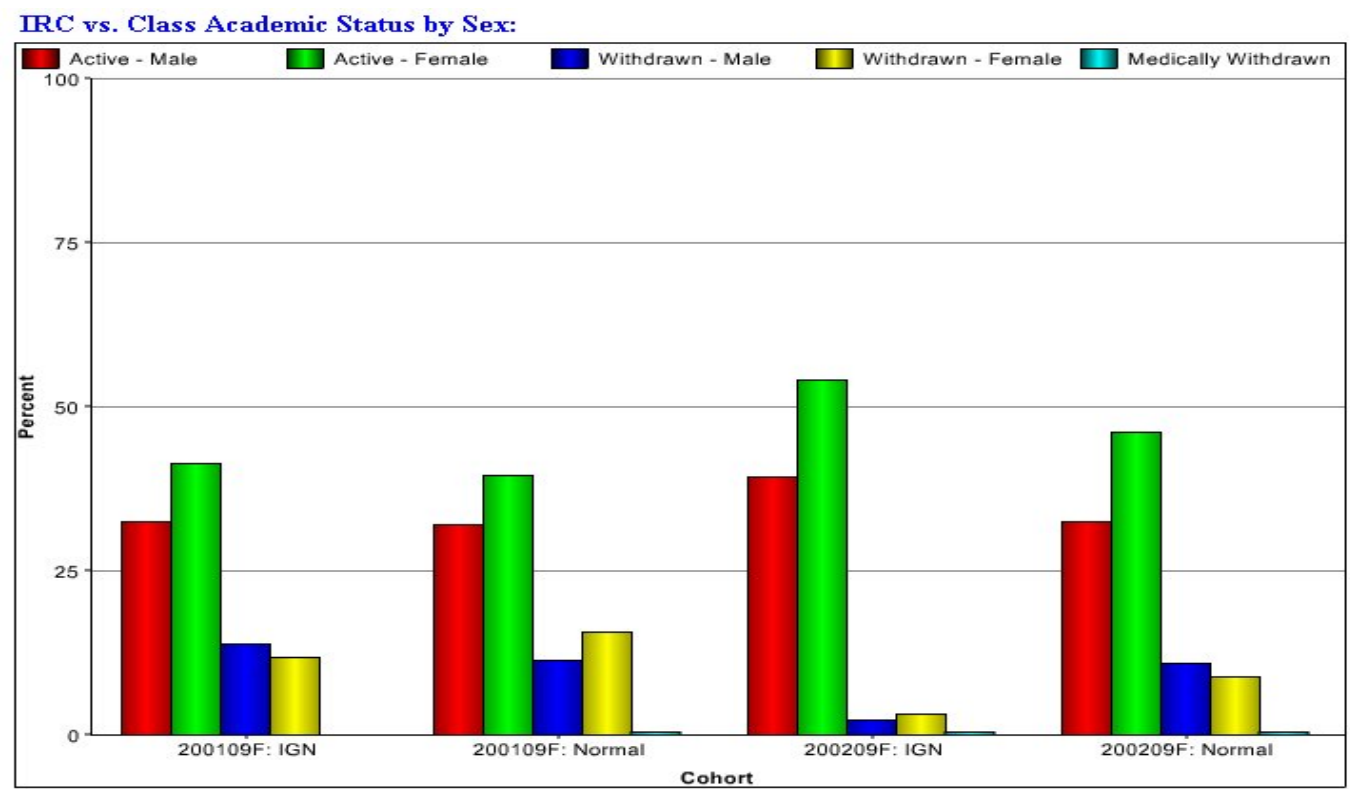

Figure 3: IRC vs. Class Academic Status by Sex (courtesy of C. Naser, 2004)

By the spring of 2003, as the residents for the next academic year were beginning to apply, the admission process had become more complex, and parameters for acceptable personal characteristics had been clarified. There had been a dozen students (and one resident advisor) who had either been forced or had requested to transfer out of the Ignatian Residential College. Some of those had been "excommunicated" because of violations of the University rules (drinking, fighting), but some had been excommunicated because they violated the norms of community being established in Loyola Hall. The norms for appropriate conduct (such as not drinking alcohol in the residence hall) were flouted by some students despite their agreement to abide by them, although at a lower rate than across the general student population.

Given the many positive markers of community noted by the students during the first two years, such instances of alienation or misbehavior were given considerable attention by the programs directors. Ongoing conversations with the residence hall director, a graduate student, indicated that an uncomfortable number of incidents of what she called "inappropriate behavior" marked the second and third years of the IRC although the director consistently noted with relief that the incidents occurred at a much lower rate than in any of the other residence halls. An ever clearer and stricter policy about what breaches could be mended so that the offenders could remain within community (and the residence hall) developed to protect community norms. For example, the staff proactively added several steps to the applicant sorting process. Applicants' names now are matched against the campus judicial system's list of students who have accumulated points toward disciplinary actions. IRC will exclude students who have amassed 4 or more points in disciplinary actions; and may consider students with 1-3 points as borderline.

In addition, the residential staff are now scoring the admission essays on 8 criteria, including interest in "spiritual/religious" development, openness to personal growth, current level of maturity, interest and ability to "live in community," a sense of "healthy balance" and an understanding of the goals of the Ignatian College. The criteria do not include academic indicators such as grades. Scores of 8-12 are considered excellent; scores between 21-28 are considered average, and scores between 29-40 are less desirable. Excellent scorers are admitted automatically; strong but questionable scorers, such as those with judicial or disciplinary issues, are interviewed in person. 
The directors hope that, even with the stricter admission criteria, diversity will thrive within the IRC. In fact, maintaining racial or socioeconomic diversity will continue to be a challenge both for the IRC and the University, given a significant drop in AHANA students and a 7\% rise in tuition and fees for the 2004-5 academic year. Religious diversity is scant among the students, as most are practicing Catholics. In addition, although the IRC residential staff is supportive of gay and lesbian students, the overriding student culture on campus is one where some degree of homophobia is still present, so it is difficult to gauge the distribution of gay and lesbian students living on campus. Bensimon (1994) notes that building community within a university requires attention to challenges of accommodating the diversity and differences among constituents, a challenge others have noted as well (Calderwood 2000a \& b, 2003; Magolda \& Knight-Abowitz, 1997; Varlotta, 2001).

The campus-wide socio-cultural homogeneity has, not surprisingly, been mined for any bits of identifiable diversity. The most compelling kinds of diversity for the IRC students, according to survey responses and essays, seem to be more individualistic than cultural. Personality traits such as gregariousness, reflectiveness, and friendliness; ideological sensibility, such as disengagement or engagement in various causes; or fervor of religious beliefs are some of the diversity indicators that students use. One of the more common themes expressed is that of a surprised disengagement from former friends who no longer "are like me" or who no longer "have anything in common with me," coupled with an appreciation for new friends who are different (in personality, ideology, etc.) from the former friends. A second common theme with regard to diversity is the comfort that results as students find new matches that better suit their developing self iterations. Not all of the discoveries are comforting, however, as one student noted:

After a seemingly spontaneous decision to become an RA, I interviewed for the position in Loyola Hall. Shortly thereafter, I found that my lack of religious experiences has seemingly closed a lot of doors for me. I realized that despite any spirituality I have in my heart or soul, the actual habitual practice of a specific religion matters to some people.

\section{Spirituality in Community}

Ton Dalton (2001) writes of spirituality as a quest - a quest for meaning and for connection that for the college student is dually a quest for a purpose in life and "finding an inward home (17)" propelled by a sense of personal destiny. It is characteristic of the search for college students, he notes, that the possibility, perhaps the inevitability, of feeling called, of discovering vocation, of setting one's feet upon a life path, is at once deeply personal and unavoidably public. He notes that balancing the interiority and communal dimensions of the spiritual quest can go sometimes awry when unsupported for the common good, resulting in a narcissistic, selfish pursuit of individual gratification, an observation echoed in recent research (Astin, A., 2004: Astin, H., 2004; Astin \& Astin, 2003; Estanek, 2004: Lindholm, 2004; Love, 2001; Palmer, 1998, 2000).

The students in the IRC, when asked to write about their sense of spirituality, often described it in terms of participation in a faith community. Going to Mass in the Commons was an oft-repeated example of such participation. Others wrote of a personal relationship with God that might not include visible participation in a formal faith community. While most said that their sense of spirituality had not substantially changed, some students noted that they felt it deepen, or that they understood it differently. Many of the students who wrote about spirituality used the images of journey and introspective quest, as these students do:The fact that I do not fully understand 
myself or my place in the world is no longer a source of fear or insecurity. I know it is a journey - a process. My search for meaning in life became more introverted as I began looking inside for many of the answers which I had not found through others. I do feel that I am more aware of how I relate to the world around me and I feel I have come closer to my search for meaning although I don't know if I will ever fully grasp it.

\section{Caring for the Whole Person}

$\mathrm{T}_{\mathrm{r}}$ he mentoring and modeling provided for the students in the college, particularly in the guided reflections expected for participation in the mentor groups, has perhaps been the most appreciated element of the Ignatian Residential College. Extensive scaffolding provided for the reflection is necessary, for the students find the communal reflective experience to be particularly challenging. The props-beautiful journals, bookmarks, and such-are visible and portable reminders and organizers that can easily be incorporated into the personal items routinely lugged around by the students. The time required to read, think and write, however, requires commitment and a degree of sacrifice on the part of the students, and must be balanced with the academic, cultural, athletic, and social obligations or opportunities that define the work and play of the student. In their response to residential surveys distributed late in the fall 2003 semester, a significant majority of the responding students noted that participation in the mentoring groups was the most challenging aspect of their membership in the Ignatian College. They cited two elements: time for preparation, and the willingness to be open about sharing their reflections about the mostly spiritually oriented readings and accompanying reflection prompts. Consistently, however, the students have noted that they value the mentoring groups almost as highly as they do the friendships formed in community. When asked what they would like to continue after they left the Ignatian College, many students said they would like to continue participating in structured mentoring groups, or that they would maintain relationships with their mentors and group members (See Figure 4). One student wrote in April 2004:

I enjoyed having a mentor who was an adult available for me to talk to about anything. She wanted to spend time with us, and she cared about our lives ... At school, I don't get the feedback and support from adults like I did when I was younger, so having a mentor for support throughout the year has really helped me. I made a lot of important decisions this year. Sue helped me so much to decide things!

Not every student, in his or her final reflections, found praise for the mentor group experience. A small number of the students found the reflections encouraged in the mentoring group to be shallow and self-centered. One woman thought that the groups should concentrate on pressing social concerns (war, poverty) rather than obsess with what she saw as a self-indulgent focus. 


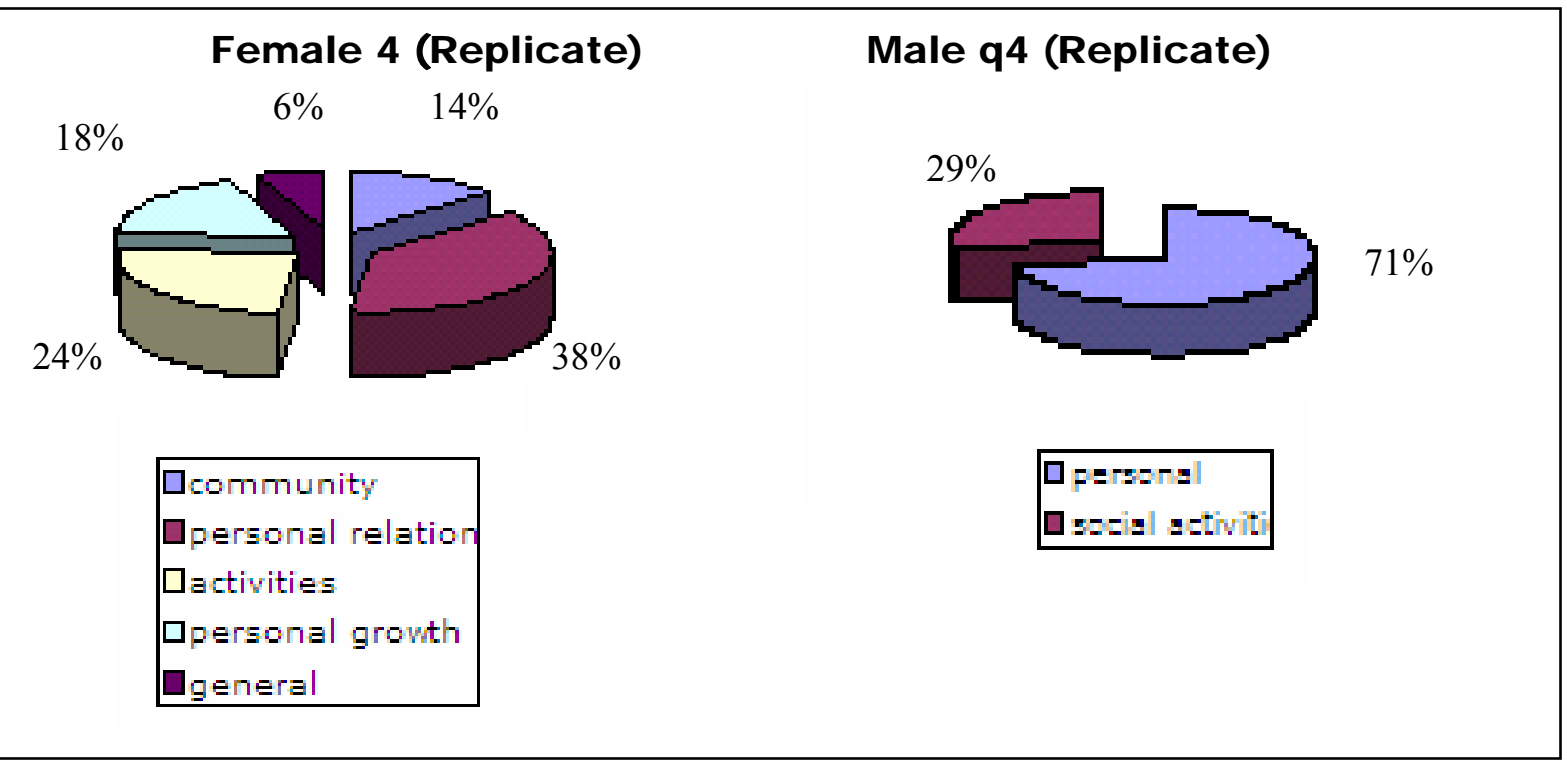

Figure 4: Student responses to question: What will you replicate next year?

\section{Living in Community}

Tucker (1999), noting that a strong sense of community is a positive factor in student retention, makes the important point that for students, a sense of community is predominantly encapsulated by an overall feeling of acceptance and belonging in campus academic, residential, and social settings. He suggests that this is a comprehensive and irreducible set, so that a significant sense of isolation or alienation in any of the settings affects a student's sense of belonging across the spectrum, a point echoed across the recent literature (Anchors, Douglas \& Kasper, 1993; Astin, A. 2004; Astin, H., 2004; Baxter Magolda, 1993; Baumeister, 2004; Braxton \& McClendon, 2001; Johnson, 2004; McDonald \& Gillespie, 2004; Taub, 1998; Varlotta, 2001; White \& Porterfield, 1993; Winston \& Anchors, 1993).

For many of the students, living in community, as opposed to just occupying a dorm room, was an unexpectedly rich experience. Quite a few students wrote of miserable freshman years marked by loneliness, isolation, and a feeling of not belonging. As sophomores, they found the carefully constructed communal climate in Loyola Hall to be a welcome contrast. As one woman wrote,

To me, the greatest part of the Ignatian Residential College is the sense of community and belonging. It is comforting to live with people who are at the same point in their lives and going through the same things. It is good to know that we are not alone in this confusing time in our lives.

In the fall of 2003, students wrote about challenges they faced in adjusting to various elements of community commitment in the college:

Most challenging has been the sharing of my personal life with strangers, even though after a while we have become friends. The most challenging aspect is dealing with people who applied to the program because they wanted to live in Loyola and not because they wanted to be part of the program. Explaining to my friends outside of the college that we are not crazy. 
Willie (1995) reminds us of the twinned responsibilities of community: that of the individual toward the group, and that of the group toward the individual (see also Frazer, 1999; Frazer \& Lacey, 1993. Students in the Ignatian Residential College are encouraged to carry out their communal responsibilities, as well as to accept and appreciate the personal benefits that they receive. For example, residents are expected to use provided doorstops to keep their room doors open during the early evening hours in order to facilitate interaction and reduce isolation.

In response to resident surveys distributed in November 2003, many students wrote that they found the social relations of community to be very important. One woman wrote, when asked what she most appreciated, "The sense of community \& safety (w/o vandalism) in this dorm. Last year I didn't get to meet that many people so this has been wonderful. It really feels like a family sometimes which is something most of us miss whether we admit it or not." Another student, male, found "the community that I've become a part of" most valuable.

During a conversation about the cluster of departures, both forced and voluntary, that marked the second year, the resident director noted an interesting element in some students' decision to apply. Students who had had unhappy freshman years, and students who were considering leaving the university because they didn't find it to be a good fit for their social, cultural, or emotional selves, saw the IRC as offering hope and comfort, or sometimes as a final testing ground for the University to prove that it could offer what they needed. For some, naturally, this desperation or this ultimatum yielded further disappointment. I spoke at length with one lonely Latina several times during the spring of 2003, who confided that she still did not feel included in community, even though she appreciated much of what the IRC offered her. She told me a sad story of thoughtless cruelty she experienced over the Thanksgiving holiday, remembering that the women she had earlier considered friends had abandoned her and had abruptly cut short a weekend visit to her apartment in the Bronx, rejecting her hospitality, her culture, and her self. As she had seen the IRC as a last hope opportunity to feel included and valued in community on campus, this experience was shattering. Over the summer, she transferred to another university to finish her studies.

Excerpts from comments written by two of the students who were required to leave during the 2003-2004 academic year give a sense of the range of understanding of and commitment to the bonds of community in the college, and to the related challenge of understanding that these bonds of community require that certain behavioral and attitudinal norms be learned. The first letter illustrates a sense of rupture and sincere regret for the damage to community resulting from a foolish choice. In a letter written to the directors who were about to decide whether to require this young man to leave the residence hall, and thus the community, after he had violated University rules about alcohol use in the dorms, the remorseful student blends his contrition with his own sense of impending loss:

I still see all of you as mentors and/or friends of mine that I have gained through my experience in Ignatian thus far... No amount of words can take back my actions, yet I'm still not digging for excuses. ... I could walk down any hall and spark a conversation with almost anybody, including one of you. It is such a comfortable place to call my home away from home. When I went to bed Saturday night I started thinking of life outside of Loyola, even away from Fairfield, and believe me I had the most horrific of nightmares. I guess I didn't appreciate what I had until I realized all that could be taken away from me. . . . . Living in the Ignatian Residential College is one of the most fulfilling 
experiences that I have had. . . . I apologize from the bottom of my heart for the disrespect that I have shown... (Student, personal communication, December, 2003).

Another student, considering his impending forced departure from the residence hall and the program, although acknowledging that he transgressed, does not seem to understand that his actions have been experienced as a violation of community trust. He sought, unsuccessfully, to call upon the more superficial bonds of community to bring him mercy, in this letter written to the resident director just before he was referred to the University Judicial System for disciplinary action:

I know you have to do your job and what happens happens. But I feel that this should of maybe been worked out in our community. The whole theme of Ignatian pushed the idea of community and working together. When something bad happens unfortunately in a community, the community tries to work it out . . . . I am a good kid and get along with basically everyone. If we could work something out between you and I instead of working it out with judicial will be great (Student, personal communication, February, 2004).

\section{Learning In Community}

Tn all four semesters of data collection, students noted in their course surveys that they most Lappreciated the development (in depth and scope) of their habits of mind. Many of the comments students made about what they noticed and appreciated about the courses include enthused statements about the specific course content, such as biodiversity, ethics, Dante, business models, and so on, which stand in stark contrast to the most frequently reported reasons for taking the classes, scheduling convenience or adherence to the requirement to take an Ignatian course. In two science classes, students learned that "science is not absolute, questions of human life are still open, " and were challenged to think about the "integration of evolution and religion." Students found that they constructed a "basis to make moral decisions" and learned about "many different perspectives." There were constant "opportunities to ponder on important moral issues."

A substantial number of student comments can be categorized as related to course design, such as appreciation for journal writing, projects, group discussions, interesting papers, guest speakers, professor lectures, and so on. Many of the students wrote that they appreciated the sense of community, the comfortable flow of conversation, the freedom to speak their minds, the overall climate of the class, and similar considerations. They wrote that "the teacher was close to the students," there was "time for personal reflection," there was "room for our interpretation," "there was a very friendly mood," and that they felt "a sense of community." They noticed that "the teacher cares about the subject."

A smaller, but noticeable number of student comments were about the development of their personal identity through the interactions and activities of the classes. Some of these were explicitly spiritual, but more of the comments were about their increasing sophistication and maturity, self-awareness, and changes in how they understood their relationship to others and their responsibilities as human beings or concerned citizens. Comments include: "The course changed my thinking and life," "I care more about the environment." 


\section{Carrying A Sense Of Community Forward}

Students who participated in the first year of the IRC indicated a desire to continue many of the community building and personal reflection activities and relationships that so enriched their year in residence. Their desire matches the hope on the part of the steering committee that the IRC act as a positive transformative movement on campus, and is echoed in the explanation of the Companions program, newly instituted for the student alums of the IRC:

It has always been our hope that alumni/ae of the Ignatian Residential College would provide a leaven on campus that over time might transform the very nature of the undergraduate student body in terms of explicitly highlighting within the undergraduate experience the Jesuit goal of educating the "whole person." By year three of operation, nearly six hundred students will have experienced the positive integrating dimensions that form the explicit foci of the Ignatian College. After the success of our inaugural year we have realized that in order for that leavening effect to take place, our alumni/ae need a venue through which we can keep them personally engaged with the College's goals and initiatives.

To do so, we created a new Ignatian College Alumnus program called "Companions". This program provides opportunities for alumni/ae to share, reflect, continue the developmental process of their sophomore year, and to assume a leadership role within the wider student body to promote the goals of the program. Components of the program include re-gathering events, group meetings, intensive training weekends and a university-wide weekend retreat.

These components help us achieve the goals of: helping individual alumni/ae build upon the personal exploration achieved during their sophomore year; developing leadership skills for alumni/ae to be used in service of fellow students in junior and senior year; helping transform the general culture of the student body, drawing upon the spiritual and intellectual roots of Fairfield's Jesuit heritage (Mayzik, 2004).

During its first two years, the Ignatian Residential College has become an increasingly important enterprise on our campus. Through its articulation of an interrelated intentional and learning community, it has provided substantial opportunity for students to push back isolation and disconnection and to feel a sense of purposeful connection. Yet, the nuances of the notion of vocation have simultaneously attracted and repelled potential student members. For some scoffers, the IRC is cult-like, for others it is the best possible residential experience on campus. Membership norms for students have sometimes been perceived as exclusionary or chafing, but also have been noted as highly valued and important.

The slight differences and significant redundancy in how the idea of community was elaborated within intentional or learning community generally increased the overall depth and strength of resilient community among the students during those first two years. However, the potential for fragmentation and fragility were ever present. Some students, for example, sometimes noted alienation and loneliness despite the numerous opportunities to experience a sense of community. Reluctant students manage to engage only superficially with mentors. Students still sometimes made immature choices about alcohol use.

Despite the occasional fragility of the communal bonds, however, the overall vibrancy and health of the Ignatian Residential College has been vigorous. Instances of fragility, whenever they came 
to the attention of the staff, were not left to fester. Those few instances of fragility, such as the unhappiness of the Latina student I interviewed, that did not come to the attention of the staff in a timely manner, were borne fairly quietly by individual students rather than taken on by the larger community. Although this pained the staff, they accepted that they could not possibly know about, or find solutions to, every disillusionment that arose. The students, in general, also understood and accepted such limitations on the community's ability to keep all members content. An acceptable balance was carefully maintained, and a positive sense of community among the students has flourished.

\section{References:}

Anchors, S., Douglas, K. B., \& Kasper, M.K., (1993). Developing and enhancing student communities. In Roger Winston, Jr. and Scott Anchors (Eds.) Student housing and residential life: A handbook for professionals committed to student development goals (461-481). San Francisco: Jossey-Bass Publishers.

Armstrong, M. (1999). Models for faculty-student interaction outside of the classroom: the Duke University Faculty Associates Program. College Student Affairs Journal, 19 (1), 4-16.

Astin, A. (1993). Higher education and the concept of community. Office of Publications, University of Illinois, Urbana-Champaign.

Astin, A. (2004). College students' spirituality: Its meaning and expression. Paper presented at the $14^{\text {th }}$ Annual Institute on College Student Values, Tallahassee, Florida, February 5-7, 2004.

Astin, H. (2004). In their own voices: Students' spirituality and the college. Paper presented at the $14^{\text {th }}$ Annual Institute on College Student Values, Tallahassee, Florida, February 5-7, 2004.

Astin, A. \& Astin, H., (2003). Are students on a spiritual quest? The Dallas Morning News, November 29, 2003.

Baumeister, R. (2004). Life's meaning, the self, and the value gap. Paper presented at the $14^{\text {th }}$ Annual Institute on College Student Values, Tallahassee, Florida, February 5-7, 2004.

Baxter Magolda, M. B. (1993). Intellectual, ethical and moral development. In Roger Winston, Jr. and Scott Anchors (Eds.) Student housing and residential life: A handbook for professionals committed to student development goals (95-133). San Francisco: JosseyBass Publishers.

Bensimon, E. M. (1994). Bilingual cash machines, multicultural campuses, and communities of difference. Innovative Higher Education, 19, (1), 23-32.

Braxton, J.M. \& McClendon, S. A. (2001). The fostering of social integration and retention through institutional practice. Journal of College Student Retention, 3 (1), 57-71.

Calderwood, P. E.(2003). Toward a professional community for social justice. Journal of Transformative Education, 1, (4), 301-320.

Calderwood, P. E. (2000a). Learning community: Finding common ground in difference. New York: Teachers College Press.

Calderwood, P. E. (2000b). When community fails to transform: the raveling and unraveling of a community of writers. The Urban Review, 32, (3), 263-292.

Cohen, A. (1985). The symbolic construction of community. London: Routledge.

Cohen, A. (1994). Self consciousness: an alternative anthropology of identity. London: Routledge. 
Cohler, B. J. \& Taber, S. E. (1993). Residential college as milieu: person and environment in the transition to young adulthood. Residential Treatment for Children \& Youth, 10, (3), 69110.

Dalton, J. C. (2001). Career and calling: Finding a place for the spirit in work and community. New Directions for Student Services, (95), 17-25.

Ellen, R. F. (1984) Ethnographic research: a guide to general conduct. London: Academic Press.

Estanek, S. (2004). A conceptual taxonomy of spirituality. Paper presented at the $14^{\text {th }}$ Annual Institute on College Student Values, Tallahassee, Florida, February 5-7, 2004.

Frazer, E. \& Lacey, N. (1993). The politics of community: a feminist critique of the liberal communitarian debate. Toronto: University of Toronto Press.

Frazer, E. (1999). The problems of communitarian politics: unity and conflict. New York: Oxford University Press.

Hartley, M. \& Hollander, E. (2003). The higher purpose of higher education. @PennGSE: A review of research, 1 (2), 3-5.

Haworth, J.G., Cooper, G., Sucher, S. \& Sullivan, E. E. (2004). Being called and the caller: Exploring vocation and spirituality in college students. Paper presented at the $14^{\text {th }}$ Annual Institute on College Student Values, Tallahassee, Florida, February 5-7, 2004.

Jacoby, B. (1997). Learning communities and commuter students. The Commuter, 22 (1), 5-7.

Johnson, T. (2004). Religious and spirituality in college students: Separate dimensions with unique and common correlates. Paper presented at the $14^{\text {th }}$ Annual Institute on College Student Values, Tallahassee, Florida, February 5-7, 2004.

Knight-Abowitz, K. (1997). Neglected aspects of the liberal-communitarian debate and implications for school communities. Educational Foundations, 11, (2), 63-82.

Lindholm, J. (2004). The role of faculty in college students' spirituality. Paper presented at the $14^{\text {th }}$ Annual Institute on College Student Values, Tallahassee, Florida, February 5-7, 2004.

Love, P. J. (2001). Spirituality and student development: theoretical connections. New Directions for Student Services, (95), 7-16.

Magolda, P. (2000). The campus tour: Ritual and community in higher education. Anthropology and Education Quarterly, 31, (1), 24-26.

Magolda, P. and Knight-Abowitz, K. (1997). Communities and tribes in residential living. Teachers College Record, 99, 2, 266-310.

Mayzik, J. (2004). Companions: A program for alumni of the Ignatian Residential College http://faculty.fairfield.edu/jmayzik/irc/companions.html. Retrieved June 27, 2004.

McDonald, W. \& Gillespie, D. (2004). While we live, we serve: The role of community in helping students find meaning and purpose. Paper presented at the $14^{\text {th }}$ Annual Institute on College Student Values, Tallahassee, Florida, February 5-7, 2004.

Naser, C. (2004). IRC Grade Analysis. https://apps.fairfield.edu/eidos/Fac/Grades/H_IRC.cfm

Palmer, P. (2000). Let your life speak: Listening for the voice of vocation. San Francisco: Jossey-Bass Publishers.

Pike, G. R. (1999). The effects of residential learning communities and traditional residential living arrangements on educational gains during the first year of college. Journal of College Student Development, 40, 3, 269-284.

Redmond, M.C. (2003). Leading by example. Fairfield Now, Winter 2003, 12-13.

Rogoff, B. (1994). Developing understanding of the idea of communities of learners. Mind, Culture, and Activity, 1, (4), 209-226.

Rosenberg, M. (2002). When roommates are also classmates. New York Times, August 18, 2002, section 14, p. 2. 
Schroeder, C.C. \& Hurst, J.C. (1996). Designing learning environments that integrate curricular and cocurricular experiences. Journal of College Student Development, 37, 174-181.

Smith, B. L. (2003). Learning communities and liberal education. Academe, 89, (1), 14-18.

Strauss, A. \& Corbin, J. (1990). Basics of qualitative research: grounded theory procedures and techniques. Newbury Park: Sage Publications.

Taub, D. (1998). Building community on campus: Student affairs professionals as group workers. Journal for Specialists in Group Work, 23, (4), 411-427.

Tucker, J. E. (1999). Tinto's model and successful college transitions. Journal of College Student Retention, 1, (2) 163-175.

Varlotta, L.E. (2001). Using postmodern feminism to reconceptualize "citizenship" and "community." In C.E. Outcalt, S.K. Faris, and K.N. McMahon, (Eds.), (2001). Developing non-hierarchical leadership on campus: case studies and best practices in higher education (pp. 49-63). Westport, CT: Greenwood Press.

White, D. B. \& Porterfield, W. D. (1993). Psychosocial development in college. In Roger Winston, Jr. and Scott Anchors (Eds.) Student housing and residential life: A handbook for professionals committed to student development goals (65-94). San Francisco: Jossey-Bass Publishers.

Willie, C. V. (1995). Achieving community on the college campus. Multicultural Review, September 1995, 16-18, 22-23, 52.

Winston, R. B. \& Anchors, S. (1993). Student development in the residential environment. In Roger Winston, Jr. and Scott Anchors (Eds.) Student housing and residential life: A handbook for professionals committed to student development goals (25-64). San Francisco: Jossey-Bass Publisher. 